\title{
Radiomodulatory Role of Psidium guajava Leaf Extracts against X-ray Induced Genotoxicity, Oxidative stress and Apoptosis in albino Wistar Rat Model
}

\author{
Amith Kumar ${ }^{1}$, Reshma Kumarchandra ${ }^{1}$, Rajalakshmi Rai ${ }^{2}$, B. S. Satish Rao ${ }^{3}$ \\ ${ }^{1}$ Department of Biochemistry, Kasturba Medical College, Manipal University, Mangalore, Karnataka, India. ${ }^{2}$ Department of Anatomy, Kasturba Medical \\ College, Manipal University, Mangalore, Karnataka, India. ${ }^{3}$ Department of Radiobiology, Manipal School of life science (MLSC), Manipal University, \\ Mangalore, Karnataka, India.
}

\begin{tabular}{|c|c|}
\hline ARTICLE INFO & ABSTRACT \\
\hline Article history: & \multirow{12}{*}{$\begin{array}{l}\text { In the present study we investigated the radioprotective activity of hydroalcoholic leaf extracts of Psidium } \\
\text { guajava (P.G) against rats exposed to X rays. Exposure to ionizing radiation like X rays induces oxidative } \\
\text { damage in normal tissues leading to their death or transforming them into cancerous tissues. To study the } \\
\text { optimum dose of radioprotection, rats were administered with different doses }(50,100,200,400 \mathrm{mg} / \mathrm{kg} \text { body } \\
\text { weight) of Psidium guajava leaf extracts daily for five consecutive days. One hour after last administration of } \\
\text { leaf extracts the rats were treated with } 6.6 \text { Gy of x rays. } 200 \mathrm{mg} / \mathrm{kg} \text { body weight was selected as an optimum dose } \\
\text { for radioprotection based on survival analysis. Pretreatment of } 200 \mathrm{mg} / \mathrm{kg} \text { body weight of P.G leaf extract } \\
\text { increased the levels of antioxidant enzymes such as superoxide dismutase, catalase, reduced glutathione and } \\
\text { lowered the levels of lipid peroxidation, protein carbonyls and nitric oxide when compared to irradiated group in } \\
\text { liver tissue homogenates. DNA damage indicators analyzed through comet assay showed a reduction in Olive tail } \\
\text { movement and percentage DNA in tail significantly in P.G pretreated group when compared to irradiated group } \\
\text { alone. Pretreatment of P.G leaf extract at a dose of } 200 \mathrm{mg} / \mathrm{kg} \text { body weight protected cells from apoptosis which } \\
\text { was analyzed microscopically by Ethidium bromide /Acridine orange staining. Our findings demonstrate the role } \\
\text { of P.G leaf extract as a radio modulator in vivo, consequent to its powerful antioxidant activity in vitro and could } \\
\text { be beneficial in combating radiation induced damage in living systems. }\end{array}$} \\
\hline Received on: 08/10/2015 & \\
\hline Revised on: 09/01/2016 & \\
\hline Accepted on: 17/02/2016 & \\
\hline Available online: $30 / 03 / 2016$ & \\
\hline Key words: & \\
\hline Psidium guajava, Radiation, & \\
\hline Oxidative stress, apoptosis, & \\
\hline Comet assay. & \\
\hline & \\
\hline & \\
\hline & \\
\hline
\end{tabular}

\section{INTRODUCTION}

Ionizing radiation has direct and indirect effect on biomolecules leading to cell death and/or carcinogenesis. The direct effect is by attacking the single and double bonds present in double stranded DNA while the indirect effect is by reacting with nearby water molecules forming free radicals which in turn damage DNA. It is important to protect biological system against accidental and unavoidable exposure to radiation. Ionizing radiations are considered to be a major threat to living organisms due to its deleterious effects. The situation is alarming today due to rapid advancement in technology. The reasons could vary

\footnotetext{
* Corresponding Author

Dr. Reshma Kumarchandra, Associate professor, Department of Biochemistry, Kasturba Medical College, Manipal University,

Mangalore, Karnataka, India. Telephone number: 9845284056.

Email: reshma.kc@manipal.edu
}

from treatment strategies as in cancer, to polluted atmosphere. The need to protect oneself from the hazards of radiation is extremely essential. Plants and herb extracts have served a great deal in this regard (Jagetia, 2007). Some of the chemical components that contribute to the protective mechanisms are flavonoids, phenolic acids, xanthones, flavones etc. These polyphenolic compounds can behave both as pro oxidants and antioxidants depending on their concentration and cytosolic redox status (Girdhani et al., 2005) and can hence act as radiosensitisers and or radio protectors. Recently there is an increased interest towards plants derived drugs as radioprotectors. The studies done on certain plants like Zingerone (Rao et al., 2009), Saraca indica (Rao et al., 2010), Ocimum sanctum (Uma devi et al., 1999), Cynodon dactylon (Rao, 2006 \& 2008), Cymbopogon citratus (Rao et al., 2009) \& Ficus racemosa (Veerapur et al., 2009) displayed reduction in the radiation induced oxidative stress and genotoxicity. P.G (guava) is an important food crop and medicinal plant in the tropical and subtropical countries. 
Phytochemicals reported in this plant are mainly flavonoids like querticin, guajavarin, isoquerticin, Morin etc. (Lozoya et al., 1994). Guava leaf extract is capable of scavenging peroxy radicals (Hui-Yenchen, 2007). Antihypertensive and antidiarrhoeal actions of the plant is mediated by inhibiting intracellular calcium level. Aqueous extract of fruit peel showed significant hypolipidaemic and hepatoprotective effects in diabetic mice (Belemtougri et al., 2006; Rai and Mehta, 2010) and in experimentally induced liver damage in animals (Roy and Das, 2011). Chemical constituents present in P.G. displayed antibacterial, antimalarial, antimycobacterial and antioxidant activity. Since, evidences to substantiate the radio modulating effects of the crude extract of these plants are scanty, as of today, we propose to highlight the protective effects of these herbal extracts in albino wistar rat model exposed to X-ray irradiation, which could probably aid in designing treatment strategies for acute effects of radiation in general and radiotherapy for cancers in particular.

\section{MATERIALS AND METHODS}

Animals

Adult ( 8 - 10 weeks old), albino wistar rats of either sex, weighing $160-180 \mathrm{~g}$, was used in the present study. The animals were procured from the breeding colony of KMC, Mangalore. Prior approval of Institutional ethical committee was taken. Animals were housed in well ventilated polypropylene cages with paddy husk bedding maintained at $25 \pm 2{ }^{\circ} \mathrm{C}$ temperature and $50 \pm$ $5 \%$ humidity \& light (12 hours of light and dark) for the durations of the experiment. Rats were given ad libitum access to laboratory food (commercial rat pellets from Gold Mohur, Lipton India Ltd.) and water. Animal care and handling was done according to the guidelines issued by World Health Organization, Geneva, Switzerland and the Indian national science academy New Delhi India.

\section{Chemicals}

Meta-phosphoric acid, Sodium chloride (Nacl), $\mathrm{NaOH}$, Ethylene diamine tetra acetate (EDTA), Disodium hydrogen phosphate $\left(\mathrm{Na}_{2} \mathrm{HPO}_{4}\right)$, 5,5'-Dithiobis 2nitro benzoic acid (DTNB), Trichloroacetic acid (TCA), Thiobarbituric acid (TBA), Hydrochloric acid $(\mathrm{HCl}), 2,4-$ dinitrophenyl hydrazine, Ethanol, Ethyl-acetate, Guanidine hydrochloride, Hydrogen peroxide, Sodium dihydrogen phosphate $\left(\mathrm{NaH}_{2} \mathrm{PO}_{4}\right)$, Nitro blue tetrazolium chloride, procured from SRL private limited, India. Malonaldehyde bis, Sulphanilamide, N-(1-naphthyl)-ethylene diamine dihydrochloride (NED), Sodium nitrite, Riboflavin, Methionine, Ethidium bromide, Acridine orange, Triton x, Low melting agarose, Normal melting agarose \& Histopaque 1077 procured from Sigma Aldrich (St Louis, MO).All other reagents used are of analytical grade.

\section{Plant material and Extraction}

The tender leaves of Psidium guajava were collected during the months August to December 2013 from Soans nursery,
Alangar, Moodbidri, Mangalore, Karnataka, India. The plant specimen was authenticated by Mr. Surendranath Joshi, Botanist, St Aloysius College, Mangalore, Karnataka, India. The collected tender leaves were washed with running tap water. The tender leaves were shade dried at room temperature. After drying the leaves were powdered by an electrical mixer.100g of dried powdered leaves were suspended in $500 \mathrm{ml}$ of $50 \%$ methanol in water and refluxed at $50{ }^{\circ} \mathrm{C}$ in a soxhlet apparatus for 72 hours. The crude extract was concentrated by Rotary vacuum flash evaporator. The concentrated crude extract was stored at $4^{\circ} \mathrm{C}$ for further usage.

\section{Irradiation source and procedure}

The animals were restrained in well ventilated acrylic box and exposed to whole body X-ray irradiation at a distance of $100 \mathrm{~cm}$ from the beam exit point of the Linac accelerator (LINAC) at Radiotherapy Department, KMC Hospital, Attavar, Mangalore, India. The field size was $40 \times 40 \mathrm{~cm}^{2}$ with dose rate of $3.5 \mathrm{~Gy} / \mathrm{min}$.

\section{Acute drug toxicity}

Hydroalcoholic leaf extract of Psidium guajava was dissolved in double distilled water. Acute toxicity study was determined according to OECD guidelines. Animals were divided into four groups and in each group there were six animals. Animals from group first were administered with $0.01 \mathrm{ml} / \mathrm{kg}$ body weight double distilled water, while animals from group II-IV received a single dose of $500,1000,2000 \mathrm{mg} / \mathrm{kg}$ body weight of P.G leaf extract orally. After treatment animals were given ad libtum food and water and observed for 14 days for any mortality.

\section{Optimum dose selection of Psidium guajava leaf extract for radioprotection}

To study the optimum dose of plant for radioprotection, animals were divided into 6 groups. In each group there were 12 animals. First group received $0.01 \mathrm{ml} / \mathrm{kg}$ body weight double distilled water which served as sham control group. The experimental groups from II- V received different concentration of P.G leaf extract $(50,100,200,400 \mathrm{mg} / \mathrm{kg}$ body weight) orally once, for five consecutive days respectively and radiation control group was maintained. One hour after last administration of extract, animals were exposed to $6.6 \mathrm{~Gy}$ whole body irradiation of $\mathrm{X}$ rays $\&$ survival was recorded 30 days post irradiation.

\section{Biochemical estimations}

To explore the mechanism of radioprotection, biochemical parameters such as reduced glutathione, lipid peroxidation, nitric oxide, protein carbonyls, superoxide dismutase and catalase were analyzed in the liver tissue homogenates. Animals were divided into four groups with six animals in each group.

Group I (sham control group).Animals of this group received 0.1 $\mathrm{ml} / \mathrm{kg}$ body weight of double distilled water orally.

Group II (Irradiated group).The animals were exposed to the sub lethal dose i.e., $4 \mathrm{~Gy}$ of $\mathrm{X}$ rays. 
Group III (P.G leaf extract pretreated group). Animals were administered with $200 \mathrm{mg} / \mathrm{kg}$ body weight of leaf extract orally for five consecutive days.

Group IV (Combination group).Animals were pretreated with 200 $\mathrm{mg} / \mathrm{kg}$ body weight of P.G leaf extract for five consecutive days, and last dose of extract was given orally 1 hour before exposure to $4 \mathrm{~Gy}$ of $\mathrm{X}$ rays.

\section{Preparation of liver tissue homogenate}

All the animals were euthanized at 16 hours post irradiation and livers were perfused with ice cold saline.10\% homogenate was prepared with ice cold phosphate buffer saline with pH 7.4 using a homogenizer (RO-1727A Remi Motors). Tissue homogenization was done under controlled chilled condition. Catalase activity was measured in terms of decomposition of hydrogen peroxide $\left(\mathrm{H}_{2} \mathrm{O}_{2}\right)$ into water molecule, which was measured as decrease in absorbance at $240 \mathrm{~nm}$, as described by (Beers et al, 1952). Superoxide dismutase (SOD) activity was assayed by the method described by (Beaurchamp and Fridovich, 1971) based on NBT reduction. Lipid peroxidation was determined by analyzing TBA-reactive substances according to the method described by Buege and Aust (1978). The total GSH content was measured by the method of Ellman, (1959). Protein carbonyls was estimated in the tissue homogenate by the method described by Levine et al., (1994). NO production in tissue homogenates was measured by the Griess method (Green et al., 1982).

\section{Apoptosis assay in peripheral blood lymphocytes}

In this experiment, blood was collected from the experimental animals by cardiac puncture and stored in sterile heparinized vacutainers. Blood was diluted with phosphate buffer saline pH 7 in equal ratio and layered carefully on the density gradient Histopaque 1077 in 2:1 ratio and centrifuged at $3000 \mathrm{rpm}$ for 20 minutes. Lymphocytes were removed from the interface carefully and washed with phosphate buffer saline. The suspension was centrifuged to yield lymphocytes pellet. Ethidium bromide and acridine orange staining was done according to the procedure described by (Renvoize et al., 1998). The lymphocyte pellet was suspended in $1: 1$ ratio of ethidium bromide $(10 \mu \mathrm{g} / \mathrm{ml}) / \mathrm{AO}(50$ $\mu \mathrm{g} / \mathrm{ml}$ ) staining for one minute and observed immediately under florescent microscope. Total 300 cells were counted per samples and apoptotic index was calculated.

Apoptotic Index=Total number of apoptotic cells

$$
\text { Total number of cells }
$$

\section{Comet assay (Single cell gel electrophoresis)}

Comet assay is a technique used to measure DNA damage. The assay was performed according to the method described by Singh et al., (1988). The negatively charged DNA molecules migrate towards anode in the process of electrophoresis. Frosted microscopic slide was layered with $1.5 \%$ normal melting agarose. Peripheral blood lymphocytes from various groups were mixed with $0.75 \%$ low melting agarose and layered upon normal melting agarose The slides are incubated at $4{ }^{\circ} \mathrm{C}$ for one hour in ice lysis solution comprising of $100 \mathrm{mM}$ EDTA, $2.5 \mathrm{M} \mathrm{Nacl}, 0.2$ $\mathrm{M} \mathrm{NaOH}, 1 \%$ triton $\mathrm{x} \& 10 \%$ DMSO. After lysing the slides were placed in electrophoresis buffer $(300 \mathrm{mM} \mathrm{NaOH}, 1 \mathrm{~mm}$ EDTA, $\mathrm{pH} \geq 13$. The run time was 20 minutes with $300 \mathrm{~mA}$ voltage. The cells were neutralized with neutralizing buffer (0.4 M Tris, $\mathrm{pH}$ 7.4) and stained with ethidium bromide. The observation of DNA damage was done under fluorescent microscope. Komet 5 image analysis software developed by kinetic imaging (Liverpool UK) was used to assess DNA damage.

\section{Statistical Analysis}

Analysis of data was done by one way analysis of variance (ANOVA) followed by Post Hoc test, using IBM SPSS Statistics 20. $\mathrm{P} \leq 0.05$ was considered significant. Kaplan Meir survival analysis was used to determine the optimum dose of the leaf extract.

\section{Results}

Acute drug toxicity: Oral administration of Psidium guajava leaf extract at concentration 500, 1000 \& $2000 \mathrm{mg} / \mathrm{kg}$ body weight did not induce any mortality and behavioral changes up to 14 days observation period. Hence the extract has no lethal effect up to $2000 \mathrm{mg} / \mathrm{kg}$ body weight. Since there was no toxicity at $2000 \mathrm{mg} / \mathrm{kg}$ body weight, $1 / 10 \mathrm{th} 1 / 5 \mathrm{th}, 1 / 20 \mathrm{th}, \& 1 / 40^{\text {th }}$ of the dose was taken for further experiments.

\section{Optimum dose of Psidium guajava leaf extract for radiation protection}

The administration of Psidium guajava leaf extracts at $50,100,200,400 \mathrm{mg} / \mathrm{kg}$ body weight before 6.6 Gy of $\mathrm{X}$ ray irradiation resulted in 41.7,66.7,75.0,58.3 \% animal survival respectively. Because maximum survival was observed in 200 $\mathrm{mg} / \mathrm{kg}$ body weight, it was considered as an optimum dose for radioprotection and further experiments were carried out with this dose [Figure 1].

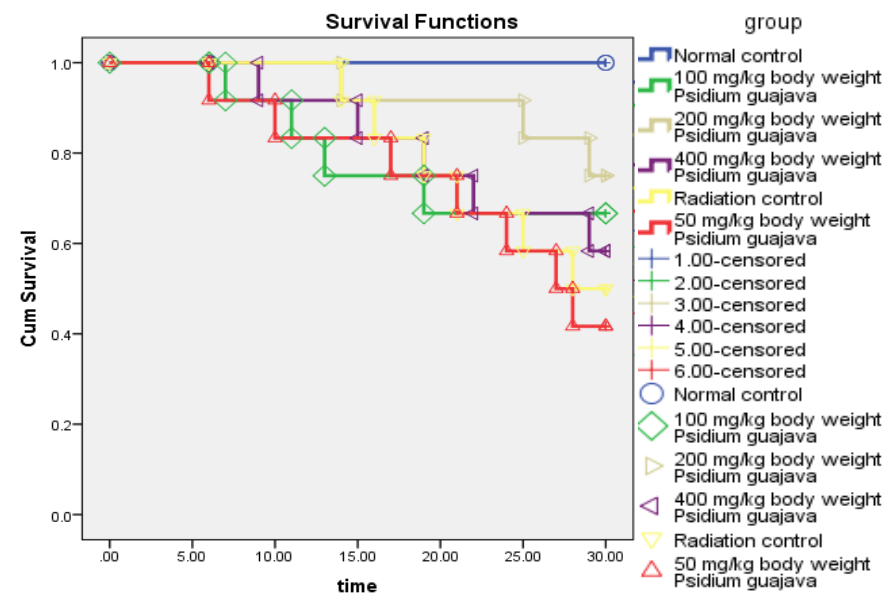

Fig. 1: Kaplan Meir survival analysis of rats administered with different dose of Psidium guajava leaf extract (50,100,200,400 mg/kg body weight) orally for five consecutive days, One Hour after last administration rats were exposed to whole body $\mathrm{X}$ ray irradiation of $6.6 \mathrm{~Gy}$. In each group 12 rats were maintained. 
Table 1 a :Induction of DNA damage assessed by alkaline Comet assay (\% DNA in tail) in peripheral blood lymphocytes of the experimental animal treated with $200 \mathrm{mg} / \mathrm{kg}$ body weight of Psidium guajava leaf extract \& in the groups exposed to $4 \mathrm{~Gy}$ of sub lethal dose of $\mathrm{X}$ rays.

\begin{tabular}{ll}
\hline Groups & \% Tail DNA \pm S.E.M \\
\hline Sham control & $1.6 \pm 0.4$ \\
Radiation control & $4.7 \pm 1$ \\
Psidium guajava & $1.1 \pm 0.3$ \\
Psidium guajava + Radiation & $1.7 \pm 0.09^{\mathrm{b}}$ \\
\hline
\end{tabular}

The significant levels $\mathrm{a}=\mathrm{p}<0.05, \mathrm{~b}=\mathrm{p}<0.01, \mathrm{c}=\mathrm{p}<0.001$ when compared to radiation group alone.

Table 1 b:Induction of DNA damage assessed by alkaline Comet assay (olive tail movement) in experimental animal treated with $200 \mathrm{mg} / \mathrm{kg}$ body weight of Psidium guajava leaf extract $\&$ in the groups exposed to 4 Gy of sub lethal dose of X-rays

\begin{tabular}{ll}
\hline Groups & Olive Tail Movement \pm S.E.M \\
\hline Sham control & $0.4 \pm 0.02$ \\
Radiation control & $5 \pm 1.3$ \\
Psidium guajava & $0.2 \pm 0.09$ \\
Psidium guajava + Radiation & $1.1 \pm 0.3^{\mathbf{c}}$ \\
\hline
\end{tabular}

The significant levels $a=p<0.05, b=p<0.01, c=p<0.001$ when compared to radiation group alone.

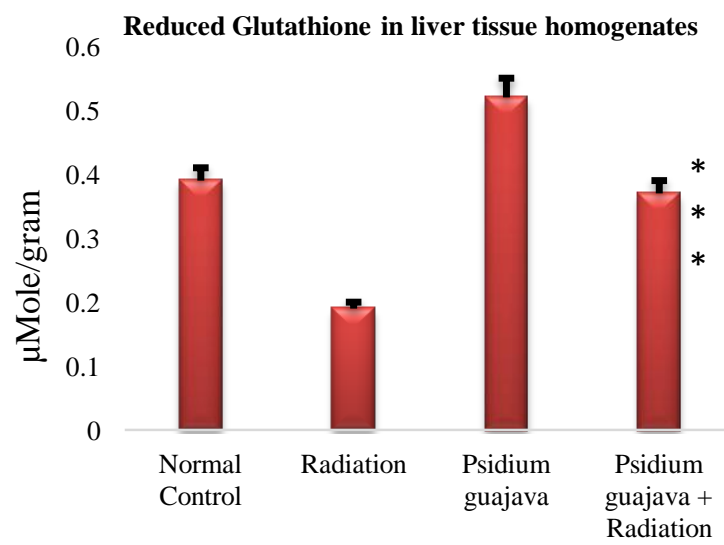

Fig. 2: Changes in reduced glutathionelevel after exposure to 4 Gy with or without $200 \mathrm{mg} / \mathrm{kg}$ body weight Psidium guajava leaf extracts given orally for five consecutive days. Values are mean $\pm S D(n=6)$. The significant levels $* \mathrm{p}<0.05$, ** $\mathrm{p}<0.01, * * * \mathrm{p}<0.001$ and no symbol $=$ not significant when compared to radiation group alone.

\section{Biochemical analysis}

Reduced Glutathione: Animals treated with whole body irradiation of 4 Gy displayed significant $(\mathrm{p}<0.001)$ reduction in the level of reduced glutathione when compared to normal controls. Pretreatment of Psidium guajava leaf extract at a dose of $200 \mathrm{mg} / \mathrm{kg}$ body weight, one hour before irradiation displayed significant increase $(\mathrm{p}<0.001)$ in the level of reduced glutathione when compared to irradiated group [Figure $2 \&$ Table 2].

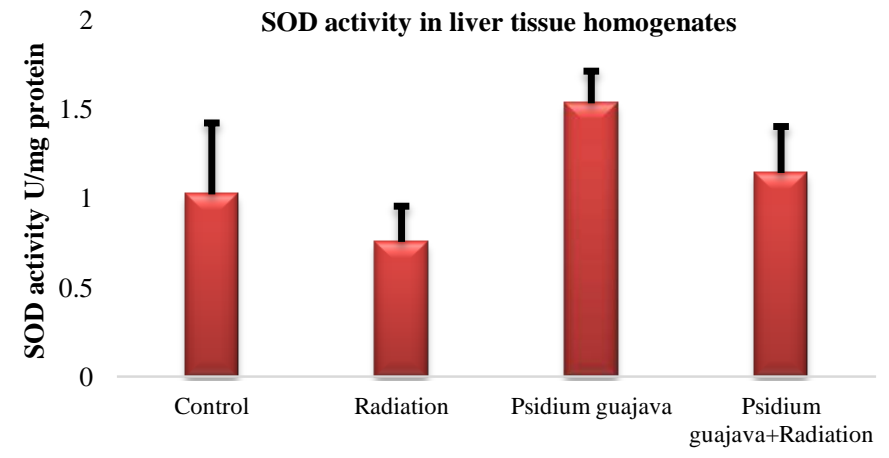

Fig. 3: Changes in Superoxide dismutase enzyme level after exposure to $4 \mathrm{~Gy}$ with or without $200 \mathrm{mg} / \mathrm{kg}$ body weight Psidium guajava leaf extracts given orally for five consecutive days. Values are mean $\pm S D(n=6)$. The significant levels $* \mathrm{p}<0.05, * * \mathrm{p}<0.01, * * * \mathrm{p}<0.001$ and no symbol $=$ not significant when compared to radiation group alone.

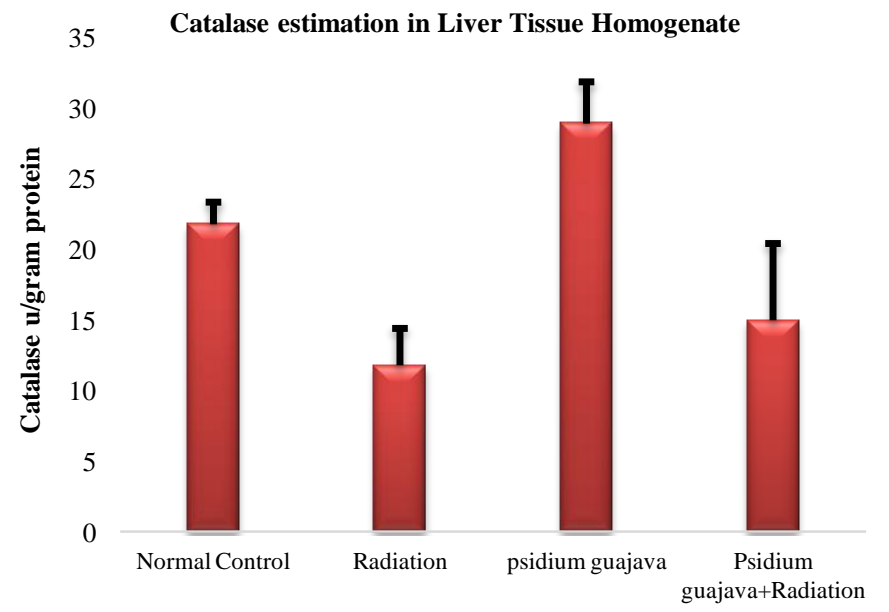

Fig. 4: Changes in Catalase level after exposure to 4 Gy with or without $200 \mathrm{mg} / \mathrm{kg}$ body weight Psidium guajava leaf extracts given orally for five consecutive days. Values are mean $\pm \mathrm{SD}(\mathrm{n}=6)$. The significant levels * $\mathrm{p}<0.05$, $* * \mathrm{p}<0.01, * * * \mathrm{p}<0.001$ and no symbol =not significant when compared to radiation group alone.

SOD: Exposure of rats to the sub lethal dose of $\mathrm{x}$ rays i.e., $4 \mathrm{~Gy}$ leads to the decline in its level when compared to control groups. Since radiation disturbs the antioxidant status of a cell it leads to depletion of SOD levels. Pretreatment of the leaf extract one hour prior to radiation significantly increased the level of superoxide dismutase enzyme $(\mathrm{p}<0.05)$ [Figure $3 \&$ Table 2] Catalase: The levels of catalase decreased in the liver tissue homogenate when rats were exposed to sub lethal dose of $\mathrm{X}$ rays i.e., 4 Gy. Pretreatment of Psidium guajava leaf extract displayed slight increase in the enzyme level when compared to irradiation alone [Figure 4 \& Table 2].

Table 2: Changes in GSH, CAT, SOD, LPO, NO and protein carbonyls levels after exposure to 4 Gy with or without Psidium guajava given orally for five consecutive days.

\begin{tabular}{|c|c|c|c|c|c|c|}
\hline Groups & $\begin{array}{l}\text { Catalase } \\
\text { U/gram } \\
\text { protein }\end{array}$ & $\begin{array}{l}\text { SOD activity } \\
\text { U/mg protein }\end{array}$ & $\begin{array}{l}\text { Protein } \\
\text { carbonyls } \mathrm{nm} / \mathrm{mg} \\
\text { protein }\end{array}$ & $\begin{array}{l}\text { GSH } \mu \text { mole/gram } \\
\text { tissue }\end{array}$ & $\begin{array}{l}\text { umole MDA/ } \\
\text { gram tissue }\end{array}$ & $\begin{array}{l}\text { Nitric Oxide } \\
\mu \text { Mole/gram } \\
\text { tissue }\end{array}$ \\
\hline Distilled water alone & $21.79 \pm 1.5$ & $1.02 \pm 0.4$ & $8.79 \pm 0.55^{\mathrm{c}}$ & $0.397 \pm 0.02^{\mathrm{c}}$ & $19.02 \pm 2.77^{\mathbf{c}}$ & $74.19 \pm 2.0^{\mathbf{c}}$ \\
\hline Distilled water +4 Gy $X$ - rays & $11.81 \pm 2.6$ & $0.754 \pm 0.2$ & $15.70 \pm 4.02$ & $0.19 \pm 0.01$ & $27.54 \pm 1.07$ & $106.7 \pm 3.6$ \\
\hline Psidium guajava leaf extract alone & $28.92 \pm 2.9$ & $1.53 \pm 0.18$ & $8.04 \pm 1.14$ & $0.52 \pm 0.03$ & $19.76 \pm 1.26$ & $77.61 \pm 6.6$ \\
\hline Psidium guajava $+4 \mathrm{GY} \mathrm{X}$ rays & $15 \pm 5.4$ & $1.14 \pm 0.26^{\mathrm{a}}$ & $10.04 \pm 1.44^{\mathbf{b}}$ & $0.37 \pm 0.02^{c}$ & $21.31 \pm 1.68^{\mathrm{c}}$ & $75.8 \pm 2.4^{\mathrm{c}}$ \\
\hline
\end{tabular}

Values are mean $\pm \mathrm{SD}(\mathrm{n}=6)$. The significant levelsa $=\mathrm{p}<0.05, \mathrm{~b}=\mathrm{p}<0.01, \mathrm{c}=\mathrm{p}<0.001$ and no symbol = non-significant when compared to group 2 against group 1 and group 4.GSH: glutathione, CAT: Catalase, SOD: Superoxide dismutase, LPO: Lipid peroxidation (MDA), NO: Nitric oxide. 
Lipid peroxidation: Rats exposed to sub lethal dose of $\mathrm{X}$ rays, displayed increase in the level of lipid peroxidation compared to that of normal controls $(\mathrm{p}<0.001)$.Pretreatment of Psidium guajava leaf extract displayed significant decrease in the level of lipid peroxidation when compared to irradiated group alone ( $\mathrm{p}<0.001)$ [Figure 5\& Table 2].

Oxidation of proteins leads to carbonyl formation. Reactive oxygen species such as hydroxyl radical, superoxide radical, peroxy radical, alkoxyl and hypochlours chloride are responsible for the oxidation of proteins. There is increase in the protein carbonyl content in liver when rats are exposed to whole body radiation of sub lethal dose (4Gy) when compared to normal control $(\mathrm{p}<0.001)$.Pretreatment of Psidium guajava leaf extract one hour before radiation displayed reduction in the protein carbonyl level which is statistically significant $(\mathrm{p}<0.01)$ [Figure 6\& Table 2].

In this experiment animals exposed to sub lethal dose exhibited an increase in the nitric oxide level when compared to normal controls which is significant. Five days pretreatment of Psidium guajava leaf extracts one hour before exposure to radiation displayed decline in the nitric oxide levels in liver tissue homogenates when compared to the irradiated group alone $(\mathrm{p}<0.001)$ [Figure $7 \&$ Table 2]

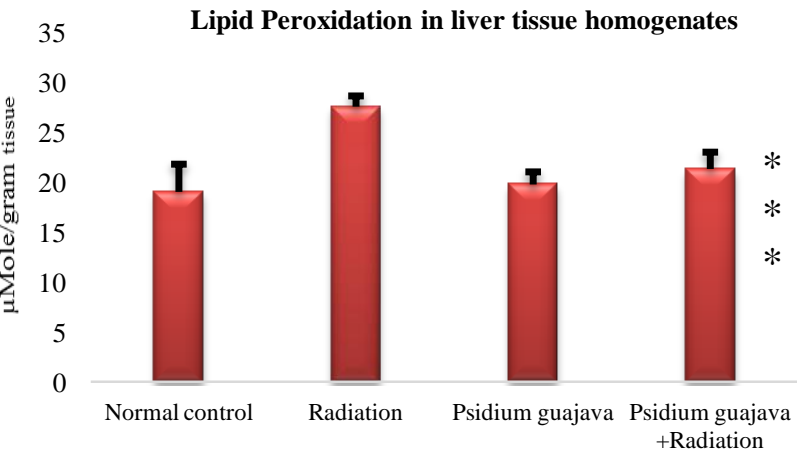

Fig. 5: Changes in Lipid peroxidation level after exposure to 4 Gy with or without $200 \mathrm{mg} / \mathrm{kg}$ body weight Psidium guajava leaf extracts given orally for five consecutive days. Values are mean $\pm \mathrm{SD}(\mathrm{n}=6)$. The significant levels * $\mathrm{p}<0.05, * * \mathrm{p}<0.01, * * * \mathrm{p}<0.001$ and no symbol $=$ not significant when compared to radiation group alone.

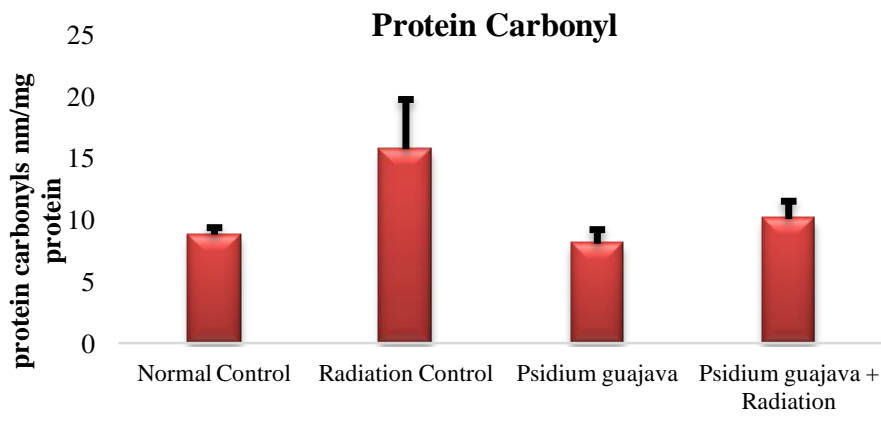

Fig. 6: Changes in Protein carbonyl content after exposure to 4 Gy with or without $200 \mathrm{mg} / \mathrm{kg}$ body weight Psidium guajava leaf extracts given orally for five consecutive days. Values are mean \pm SD $(n=6)$. The significant levels * $\mathrm{p}<0.05, * * \mathrm{p}<0.01, * * * \mathrm{p}<0.001$ and no symbol =not significant when compared to radiation group alone.

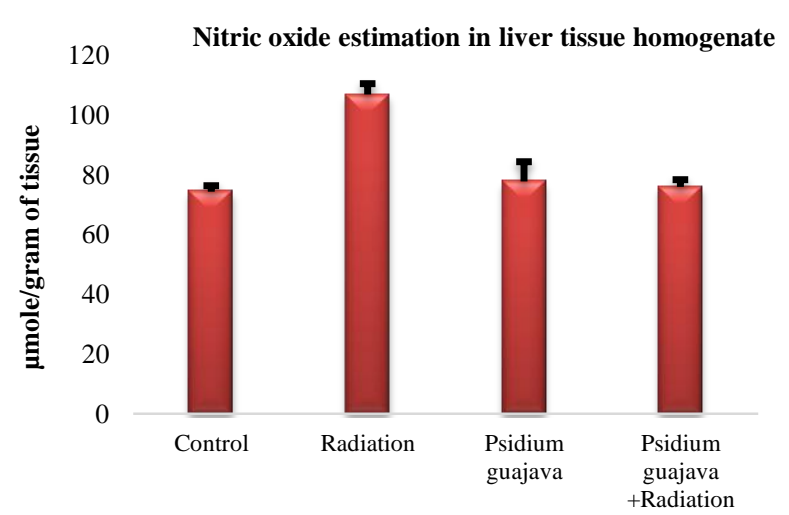

Fig. 7: Changes in Nitric oxide content after exposure to $4 \mathrm{~Gy}$ with or without $200 \mathrm{mg} / \mathrm{kg}$ body weight Psidium guajava leaf extracts given orally for five consecutive days. Values are mean $\pm S D(n=6)$. The significant levels $* p<0.05$, $* * \mathrm{p}<0.01, * * * \mathrm{p}<0.001$ and no symbol $=$ not significant when compared to radiation group alone.

\section{Apoptosis assay}

Cytomorphological analysis of peripheral blood lymphocytes by ethidium bromide/ acridine orange staining.

Ethidium bromide \& acridine orange staining is a differential stain used to analyze the morphological changes in a cell. Live cells having intact plasma membrane allows acridine orange to stain the cytoplasm. The cells which take up acridine orange fluoresce green under fluorescent microscope. If the membrane integrity is lost ethidium bromide permeates into the cell making its nucleus fluoresce red under fluorescent microscope. Animals pretreated with Psidium guajava leaf extract alone (200 mg/kg body weight) displayed green stained unfragmented nuclei, indicating non apoptotic live cells. The rats exposed to sub lethal dose of $\mathrm{x}$ rays i.e., 4Gy exhibited increase in the red stained fragmented nuclei.

There was significant increase in the apoptotic cells in radiation group alone when compared to control group ( $\mathrm{p}<$ 0.001).Pretreatment of leaf extract $200 \mathrm{mg} / \mathrm{kg}$ body weight one hour prior to radiation displayed decrease in the apoptotic index although not statistically significant [Figure 8].

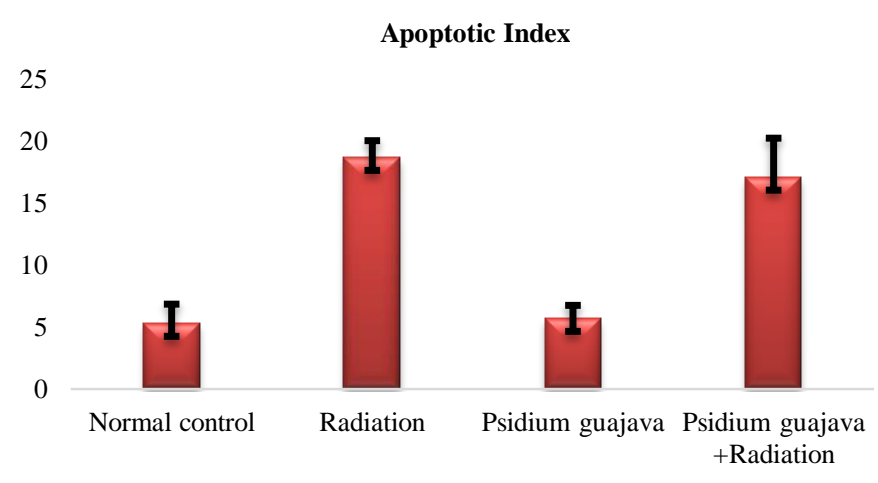

Fig. 8: Changes in Apoptotic index in peripheral blood lymphocytes after exposure to $4 \mathrm{~Gy}$ with or without $200 \mathrm{mg} / \mathrm{kg}$ body weight Psidium guajava leaf extracts given orally for five consecutive days. Values are mean $\pm \operatorname{SD}(n=6)$. 


\section{Comet assay (Single cell gel electrophoresis)}

The results of alkaline single cell gel electrophoresis is shown in table $1 \mathrm{a} \& 1 \mathrm{~b}$. In our study we found an increase in the comet parameters like percentage tail DNA and olive tail movement in rats exposed to 4 Gy of $\mathrm{x}$ ray irradiation. Pretreatment of PG continuously five days prior to radiation displayed significant reduction in the comet parameters $(\mathrm{p}<0.01)$ when compared to radiation group alone.

\section{DISCUSSION}

Ionizing radiation targeted to a cell causes radiolysis of water, generating free radicals, initiating biological damage to the cell. Hydroxyl radical thus produced causes DNA strand breaks which have been proved by in vitro studies (Rhease, 1968) producing oxidative stress in the tissues. Unsaturated fatty acids of membranes are particularly vulnerable to attack by free radicals generating lipoperoxides which have a damaging effect on cellular components (Barber, 1967). Free radicals promote oxidation of amino acid residue side chains, formation of protein-protein cross linkages and oxidation of protein back bone resulting in protein fragmentation (Berlett, 1997). Nitric oxide is reported to form peroxy nitrite which causes DNA damage by deamination of bases in DNA(Rojas ,1995). The extent of tissue damage is based on the balance between the levels of oxidants and antioxidants within the tissue (Lichttenstein, 1987). Antioxidants like glutathione (reduced) scavenge hydroxyl radicals and singlet oxygen while SOD and catalase detoxify the effects of superoxide and hydrogen peroxide respectively. Our results are well in agreement with the data reported earlier. We have observed a highly significant increase in the levels of lipid peroxides, protein carbonyls, nitric oxide and DNA damage as assessed by comet assay and apoptotic index, in the animal group exposed to a sub lethal dose of $4 \mathrm{~Gy}$ of $\mathrm{X}$-rays .This particular group has also shown a significant decrease in glutathione, SOD and catalase compared to sham control. Natural herbs have a profound influence on the free radical generating and scavenging system that operates within the body, net effect being alleviation of toxic effects induced by free radicals (Rao et al., 2008). Therefore extracts of natural herbs are advocated as supplements in free radical mediated diseases. They are reported to produce therapeutic effects on radiation induced normal tissue damage in experimental animals (Rao et al., 2009). A wide variety of natural herbs have been screened for their antioxidant and radio protective properties (Rao et al., 2010).

In our earlier studies, we have reported that Psidium guajava showed the presence of flavonoids, saponions, terpenoids, tannin and glycosides. Psidium guajava leaf extracts are potential source of natural antioxidants and has remarkably high total phenolic content (Ojan and Nihorimbere, 2004).The phenolic content such as quercetin, ferullic acid, ascorbic acid, gallic acid and guavin B reported by (Thaipong et al., 2005) are responsible for antioxidant activity. Particularly the leaves of Psidium guajava possess several plant secondary metabolites which exhibited antioxidant, antiviral and anti-inflammatory activity (Gutierrez et al. 2008; Deguchi et al., 1998; Ojewole, 2006; Mai et al., 2007).In one of the previous in vitro study which was conducted on plasmid DNA, it is reported that flavonoids and phenolic content protected the plasmid DNA by action on hydroxyl free radicals (Anderson E $\mathrm{F}$ et $a l$ ).The antioxidant supplementation enhances the endogenous antioxidant levels and helps to block DNA adduct formation which is the product of free radical DNA damage. In our earlier studies we have reported hydroxyl radical scavenging activity of $77.92 \pm$ $1.8 \%$ at a concentration of $10 \mu \mathrm{g}$ as compared to standard qurecetin which displayed $89.84 \pm 0.89 \%$ scavenging activity. A dose dependent increase in scavenging activity was observed in the crude extract. Metal chelating activity of plant extract was also observed to be increased in a dose dependent manner. At $10 \mu \mathrm{g}$ concentration Psidium guajava displayed $57.49 \pm 0.9 \%$ iron chelating activity respectively, as compared to standard disodium EDTA that displayed $75.44 \pm 0.33 \%$ iron chelating activity (Kumar et al., 2014). Further total antioxidant activity of Psidium guajava was $242.3 \pm 0.019 \mu \mathrm{g}$ compared to $100 \mu \mathrm{g}$ equivalence of quercetin and the total phenolic content in the crude extract was found to be $32.5 \pm 4.33 \mathrm{mg} \mathrm{GAE} / \mathrm{g}$ of extract. Psidium guajava displayed reducing property in concentration dependent manner and displayed around 50\% reducing property exhibited by that of standard quercetin. However the ABTS free radical scavenging effect was very weak $(28.48 \pm 2.06)$ compared to standard ascorbic acid (77.67 \pm 0.28$)$ (Kumar et al., 2015). In vivo study results presented in this work are well correlated with in vitro study results reported by us earlier. Psidium guajava has established its role as an antioxidant within the living system, particularly in the irradiated animals by significantly lowering the levels of lipid peroxidation, protein carbonyls and NO to control levels and increasing the levels of antioxidants like reduced glutathione and SOD significantly. An increase in catalase level was also observed although non-significant. Apoptotic index improved slightly by pretreatment with Psidium guajava. Apoptosis is an event that follows mitochondrial membrane damage which is a common feature in radiation. Apoptosis is initiated by various factors in which radiation is one among them. Apoptosis results in structural changes of cells like shrinkage of cells, chromatin condensation, nucleosome DNA fragmentation (Kerr et al., 1972; Sgonc and Gruber, 1998). There are evidences where antioxidants and free radicals have reduced radiation induced apoptosis (Weiss and Landauer, 2003). Study done on Hesperidin and cimetidine displayed anti apoptotic activity against cultured human peripheral blood lymphocytes when exposed to radiation (Kojima et al., 2002; Kalpana et al., 2009).Pretreatment of zingerone leads to the suppression of apoptotic morphological changes, and also reduced apoptotic index. Psidium guajava does not have a role in the protection of mitochondrial damage, based on our results. Comet assay results in the different study groups have indicated that Psidium guajava has a profound role in minimizing radiation induced double strand breaks in DNA and consequent cell death. Since plants are rich in antioxidant activity, have a role to play in reducing apoptosis initiated by radiation as per the earlier reports Psidium guajava has proved to be a good antioxidant as per our 
previous study (Kumar et al., 2015) and therefore may be effective in reducing apoptosis induced by radiation.

\section{CONCLUSION}

Psidium guajava is a powerful antioxidant in vitro and can well be used as an antioxidant supplement in vivo, to minimize the damaging effects of radiation within living system, particularly by preventing DNA damage and apoptosis. Further studies with the lead molecule in the extract, may provide valuable tools that may aid in ameliorating the harmful effects of radiotherapy on normal tissues, in cancer patients.

\section{ACKNOWLEDGEMENT}

The authors are thankful to Board of Research in Nuclear science (BRNS), Department of Atomic Energy, Bombay, Government of India for funding this project.BRNS PROJECT NO 2012/34/23/BRNS/1691.

\section{REFERENCES}

Anderson RF, Amarasinghe C, Fisher LJ, Mak WB, Packer JE. Reduction in free-radical-induced DNA strand breaks and base damage through fast chemical repair by flavonoids. Free Radic Res, 2000; 33:91103.

Belemtougri R G, Constantin B, Cognard C, Raymond, Sawadogo L. Effects of two medicinal plant Psidium guajava L. (Myrtaceae) and Diospyrosmespiliformis L (Ebenaceae) leaf extracts on rat skeletal muscle cells in primary culture. Zhejiang Univ Sci, 2006; 7:56-63.

Beers R, Sizer I. A Spectrophotometric Method for Measuring the Breakdown of Hydrogen Peroxide by Catalase. J Biol Chem, 1952; 133-195.

Beaurchamp C, Fridovich I .Superoxide dismutase improved assay applicable to acrylamide gels. Analytical biochemistry, 1971; 44: 276-287.

Buege JA, Aust S D. Microsomal lipid peroxidation. Methods Enzymol, 1978; 52:302-310.

Barber A,Bernheim F. Lipid peroxidation, its measurement, occurrence and significance in animal tissues. Adv. Gerantol, 1967; 2:355403.

Berlett BS, Stadtman ER. Protein oxidation in ageing, disease and oxidative stress. J. Biochem, 1997; 272: 203-213.

Bhuvanagiri Nageshwar Rao, Parampalli Raghavendra Archana, Balkudru Kiran Aithal, Bola Sadashiva Satish Rao. Protective effect of Zingerone, a dietary compound against radiation induced genetic damage and apoptosis in human lymphocytes. European Journal of Pharmacology, 2011; 657: 59-66.

BSS Rao, Shanbhoge R, Rao BN, Adiga SK, Upadhya D, BK Aithal MRS Kumar. Preventive efficacy of hydroalcoholic extract of Cymbopogon citratus against radiation-induced DNA damage on V79 cells and free radical scavenging ability against radicals generated in vitro. Human \& Experimental Toxicology, 2009; 28:195-202.

Chanchal K Roy, Amit Kumar Das. Effect of Psidium guajava Linn. Leaf extract on liver cell NSHM Journal of Pharmacy and Healthcare Management, 2011; 2:83-88.

Deguchi Y, Osada K, Uchida K, Kimura H, Yoshikawa M, Kudo T, Yasui H, Watamuki M: Effects of extract of guava leaves on the development of diabetes in the $\mathrm{db} / \mathrm{db}$ mouse and on the postprandial blood glucose of human subjects. Nippon Nogeikagaku Kaishi, 2010; 72:923-31.

Ellman GL. Tissue sulfhydryl groups. Arch Biochem Biophys, 1959; 82:70-77.

Gutiérrez RM, Mitchell S, Solis RV.Psidium guajava: A review of its traditional uses, phytochemistry and pharmacology. J Ethnopharmacol, 2008; 117:1-27.
Girdhani S, Bhosle SM, Thulsidas SA, Kumar A, Mishra KP. Potential of radio sensitizing agents in cancer chemo-radiotherapy. Journal of cancer research and therapeutics, 2005; 1:129-13.

Green LC, Wagner DA, Glogowski J, Skipper PL, Wishnok JS, Tannenbaum SR. Analysis of nitrate, nitrite, and [15N] nitrate in biological fluids. Anal Biochem, 1982; 126:131-138.

Hui-Yin Chen, Gow-Chin Yen. Antioxidant activity and free radical-scavenging capacity of extracts from guava (Psidium guajava L.) leaves. Food Chemistry, 2007; 101: 686-694.

Jagetia G. Radio protective potential of plants and herbs against the effects of ionizing radiation. J. Cin. Biochem Nutr, 2007; 40:74-81.

Kerr J F, Wyllie A H, Currie A R. Apoptosis: a basic biological phenomenon with wide-ranging implications in tissue kinetics. Br. J. Cancer, 1972; 26: 239-257.

Kojima, Y, Kondo T, Zhao Q L, Shoji M, Futatsuya R. Protective effects of cimetidine on radiation-induced micronuclei and apoptosis in human peripheral blood lymphocytes. Free Radic. Res, 2002; 36: $255-263$.

Kumar A, Kumarchandra R, Rai R. Free radical scavenging \& Iron chelating capacity of Psidium guajava and Persea americana leaf extract: A comparative study. Journal of Pharmacy Research, 2014; 8:728732.

Kumar A, Kumarchandra R, Rai R, Suchetha Kumari N. Total Phenolic Content, Reducing Potential \& Free Radical Scavenging Activity of Hydroalcoholic Leaf Extracts of Psidium guajava and Persea americana. Int. J. Pharm. Sci,2015; 33:290-293.

Lozoya X, Meckes M, Abou-Zaid M, Tortoriello J, Nozzolillo $\mathrm{C}$, Arnason. Quercetin glycosides in Psidium guajava L. leaves and determination of a spasmolytic principle. Arch Med Res, 1994; 25:11-54.

Lichttenstein A. Stimulation of respiratory burst of murine peritoneal inflammatory neutrophils by conjugation with tumor cells Cancer Res, 1987; 47: 2211-2217.

Levine RL, Williams J, Stadtman ER, Shacter E. Carbonyl assays for determination of oxidatively modified proteins. Methods Enzymol, 1994; 233:346- 57.

Nageshwar Rao, Satish Rao B, Kiran Aithal, Sunil Kumar. Radio modifying and anticlastogenic effect of Zingerone on Swiss albino mice exposed to whole body gamma radiation. Mutation Research, 2009;677:33-41.

Ojewole JA .Anti- inflammatory and analgesic effects of Psidium guajava Linn. (Myrtaceae) leaf aqueous extract in rats and mice. Methods Find ExpClinPharmacol, 2006; 28:441-446.

Prashant Kumar Rai, Shikha Mehta. Hypolipidaemic \& hepatoprotective effects of Psidium guajava raw fruit peel in experimental diabetes. J Med Res, 2010; 131: 820-824.

Qian H, Nihorimbere V, Antioxidant power of Phytochemicals from Psidium guajavaleaf, J Zhejiang Univ Sci, 2004; 5: 676-83.

Renvoize C, Biola A,Pallardy M, Breard J. Apoptosis: identification of dyingcells. Cell Biol. Toxicol, 1998; 14: 111-120.

Rhease HJ, Frease E. Chemical analysis of DNA alterations. Base liberation and backbone breakage of DNA and oligodeoxyadenylic acid induced by $\mathrm{H}_{2} \mathrm{O}_{2}$ and hydroxylamine. Biochem. Biophys Acta, 1968; 155: 476-490.

Rojas WT, Tamir S, Wishnok JS. Nitric oxide induces oxidative damage in addition to deamination in macrophage DNA. Chem res Toxicol, 1995; 8:473-7.

Sgonc R, Gruber J. Apoptosis detection: an overview. Exp. Gerontol, 1998; 33:525-533.

Satish Rao B S, Nageshwar Rao Archana P R, Gayathri P, Prerana Shetty. Antioxidant and Radiation Antagonistic Effect of Saraca indica. Journal of Environmental Pathology, Toxicology, and Oncology, 2010; 29:69-79.

Satish Rao B S, Shanbhoge R, Upadhya D, Jagetia G C, Adiga S K, Kumar P, Guru Prasad K, Gayathri P. Antioxidant, anticlastogenic and radioprotective effect of Coleus aromaticus on Chinese hamster fibroblast cells (V79) exposed to gamma radiation. Mutagenesis, 2006; 21:237-242

Satish Rao B S, Upadhya D, Adiga S K. Protection of ionizing radiation-induced cytogenetic damage by hydroalcoholic extract of 
Cynodon dactylon in Chinese hamster lung fibroblast cells and human peripheral blood lymphocytes, J. Environ. Pathol. ToxicolOncol, 2008; 27:101-112.

Singh NP, McCoy MT, Tice RR, Schneider. A simple technique for quantitation of low levels of DNA damage in individual cells. Exp. Cell Res, 1988; 175: 184-191.

Suffness M, Douros J. 1979. Drugs of plant origin. In: De Vita VT, editors. Methods in cancer research. New York: Academic Press. pp. 73-94.

Uma Devi P, Ganasoundari A, Satish Rao B S, Srinivasan K K. In vivo radioprotection by ocimum flavonoids: survival of mice. Radiat Res, 1999; 151:74-78.

Veerapur V P, Prabhakar KR, Vipan kumar Parihar, Machendar Reddy Kandadi, Ramakrishana S, Mishra B , Satish Rao BS, Srinivasan KK, Priyadarsini K I, Unnikrishnan M I. Ficus racemosa Stem Bark Extract: A Potent Antioxidant and a Probable Natural Radioprotector, eCAM,2009; 6:317-324.

\section{How to cite this article:}

Kumar A, Kumarchandra R, Rai R, SatishRao BS. Radiomodulatory Role of Psidium guajava Leaf Extracts against XrayInduced Genotoxicity, Oxidative stress and Apoptosis in albino Wistar Rat Model. J App Pharm Sci, 2016; 6 (03): 058-065. 